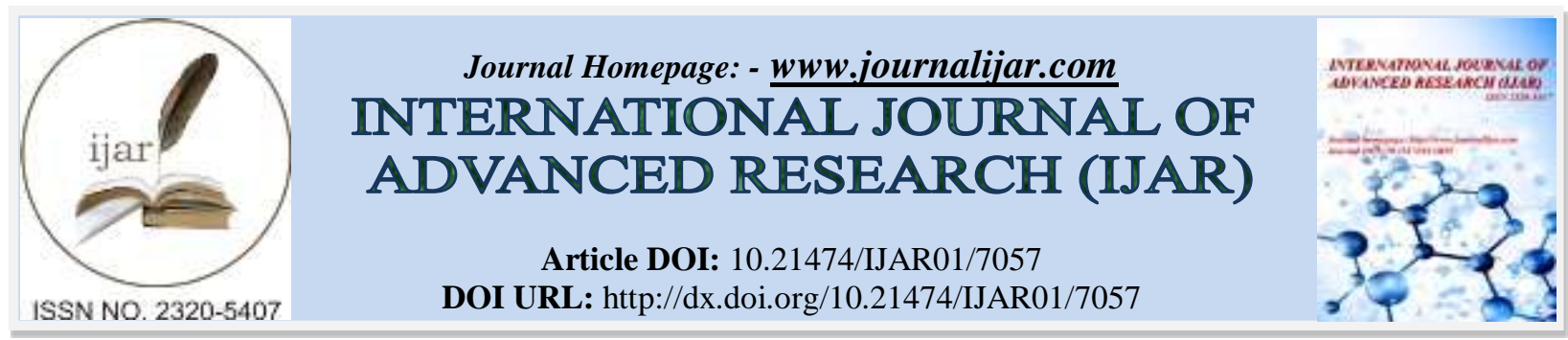

RESEARCH ARTICLE

\title{
MODEL DESIGN OF SPECIALTY COFFEE PACKAGING STRUCTURES.
}

\author{
Zulkarnain $^{1,2}$, Machfud ${ }^{3}$, Marimin $^{3}$, Emmy Darmawati $^{4}$ and Sugiarto $^{3}$. \\ 1. The Graduate School, Bogor Agricultural University, Bogor, Indonesia. \\ 2. Printing and Packaging Technology, Jakarta State Polytechnic, Depok, Indonesia. \\ 3. Department of Agroindustrial Technology, Bogor Agricultural University, Bogor, Indonesia. \\ 4. Department of Mechanical and Biosystem Engineering, Bogor Agricultural University, Bogor, Indonesia.
}

\section{Manuscript Info}

Manuscript History

Received: 07 March 2018

Final Accepted: 09 April 2018

Published: May 2018

Keywords:-

specialty coffee, packaging structure, QFD approach, decision tree.

\begin{abstract}
Consumer buying interest towards the coffee product is affected by packaging. This is because of the uniqueness of each coffee packaging produced by the manufacturer. Apart from graphic design, packaging structure also needs to be considered. The packaging structure must be suitable in order to get flavour and aroma last longer. This study aimed to identify the most influential attributes and generate decision tree to determine the packaging structure of specialty in coffee products. The Function Analysis System Technique (FAST) method was used to generate packaging structure attributes based on the functionality of specialty coffee packaging structures. Attribute of weighting packaging was done with pair wise comparison method. HOQ connected attributes of packaging structures and design elements of specialty coffee packaging structures. The C4.5 technique (a development of Iternative Dichotomizer / ID3) was used to design the decision tree of packaging structure determination. Based on the FAST analysis and pair wise comparison method, the highest attribute of packaging structure was that it could make coffee aroma recognizable easily, protect the coffee quality, be opened and closed again easily, give the impression of premium quality, and have economical price. HOQ analysis generated priority in structural design elements in sequence, using a zipper, using a valve, using a packaging form such as a pouch, using aluminium foil as the inner, having the most desirable size, using outer surface of the material, and having the colour of the surface material. After modelling, it was concluded that the influential design elements in the determination of pouch type packaging structures were zipper, surface material, and size. This research succeeded in formulating decision tree to determine the structure of specialty coffee packaging with pouch type. The level of accuracy on testing model for the determination of packaging with pouch type was $100 \%$. The conclusion of this research is that the valve element has no effect in determining pouch type packaging, but every pouch type chosen based on consumer preference analysis result must be equipped with valve.
\end{abstract}

Copy Right, IJAR, 2018,. All rights reserved. 


\section{Introduction:-}

Consumer expectations towards quality and product packaging have a positive relationship with buying interest (Holmes \& Paswan, 2012). Packaging attributes are the success determinant of micro enterprises going to global (Abidin et al., 2014). Packaging is a container to increase the value and function of a product (Julianti, 2014). Packaging has added value and is the key to sell a product in the market, as well as imported products that seem good and expensive because it is packaged well.

Consumers tend to pay attention to differences of every package of coffee on the market and buy what they like based on their perceptions (Harith et al., 2014). Packaging is proved to be one of the important factors in the success of promoting product sales (Mohebbi, 2014). Packaging is a great influencer for consumers (Moutaftsi \& Kyratsis, 2016).

The design of coffee packaging attributes should pay attention to the coffee product attributes which are flavour and aroma which are with the highest important attributes in coffee products (Satyajaya et al., 2014; Gadung et al., 2015). By understanding the influential attributes, it will help in making the right decisions about the product packaging (Zekiri, 2015). These attributes can be captured and extracted based on literature, field observations, and stakeholder opinions (consumers, business actors, and experts).

Coffee is one of the essential commodities and widely traded in the world with such taste preference from various consumers to enjoy a more diverse flavour leading to specialty coffee (Udayana, 2015). Specialty coffee has a premium price coffee. This is because the specialty coffee is mainly defined by its excellent and unique flavour (Piccino, 2014).

Activities to enjoy coffee is not just a routine, but it has become a lifestyle. The sensation of taste and aroma of coffee has become its main attractiveness. But once the packaging is opened, the coffee starts to be oxidized by the oxygen. This condition causes the flavour and aroma of coffee will be decreased. Packaging structure influences on the moisture content of coffee. Coffee packaging structure should be suitable, in order to keep the aroma, flavour, and freshness last longer, even more than three months, especially for specialty coffee products that have a distinctive aroma and flavour.

The development of coffee agribusiness have been undertaken by the government, but there are still many obstacles, especially in maintaining the product quality to meet international market standards (Udayana, 2015). Coffee quality will be maintained if it is supported by good packaging structure that keeps the flavour and aroma. Therefore, this study aimed to identify the attributes that affected the specialty coffee packaging structure and generated decision tree of packaging structure determination for specialty coffee products.

\section{Methodology:-}

\section{A. Time and Place of Research}

The research was conducted in Jakarta, Depok, and Bogor. Phase I field observation was conducted by collecting information from coffee supplier and coffee shop at the Jakarta Coffee Week exhibition at Hypeland Pantai Indah Kapuk on September 10, 2017. Second phase observation was at coffee shops on October 23, 2017 - November 21, 2017. They were JPW (Jakarta), Kimung Coffee (Depok), Ranah Kopi (Depok), Coffee Obrol (Depok), DO Coffee (Depok), Ranin Coffee House (Bogor), and MM Cafe (Bogor).

\section{B. Data Collection}

Attribute data and structural design elements were derived from literature, consumers, specialty coffee businesses, suppliers of coffee packaging, and trusted websites. Various assessment data were obtained from consumers, producers (specialty coffee businesses), and experts.

\section{Method of Analysis of Attributes and Packaging Structure Element}

Function Analysis System Technique (FAST) method was used to map attributes of packaging structures based on the function of specialty coffee packaging structures. The functions and attributes of packaging according to the specialty packaged coffee structure functions were inventoried, based on literature sources, field observations, and discussions with consumers. Furthermore, the functions and attributes of the packaging to be achieved were mapped in the FAST diagrams. 
In this method, each was bordered by an objective function that was placed on the left and the main functions on the right, using two questions "how " and "why". In writing, the packaging function on the FAST diagram included a verb (Verb) and a noun (noun) so that the functions were clear and written correctly. HOQ linked the structural attributes of packaging and structural design elements for specialty coffee products. In the application of this QFD, it involved consumers, businesses, and academic experts.

The Quality Function Deployment approach was used to evaluate consumer and producer expectations and generate priority structural design elements. The data were analysed based on the components in House of Quality (HOQ) as a part of QFD method and presented in HOQ chart (Suryaningrat, 2016). The output that generated from the QFD approach was the priority of structural design elements in packaging design. House of Quality (HOQ) was a tool in QFD method which in this research was arranged with several stages, as follows:

1) Matrix Relationship between Packaging Structure Attribute (What) with Structural Design Elements (How):

- Arranged the packaging structure attribute, then calculated the weighting using the Pairwise Comparison method based on expert judgment. To determine consistency assessment of packing structure attribute, Consistency Ratio (CR) was calculated in accordance with formula developed by Saaty \& Vargas (2012):

$$
\begin{gathered}
C R=\frac{C I}{R I} \\
C I=\frac{\left(\lambda_{\max }-n\right)}{n-1},
\end{gathered}
$$

Where, $\lambda_{\max }$ was the maximum eigen value of pair wise comparisons matrix, $\mathrm{n}$ was the number of alternatives, and RI was the random index.

- Determined the design elements of the packaging structure by conducting literature studies and interviews

- Determined the relationship of attributes of consumer packaging structure with structural design elements. At this stage of assessment was carried out to determine how strong the relationship between the attributes of the packaging structures with structural design elements were. The provisions were as follows: score 0 meant no relationship, score 1 meant weak relationship, score 3 meant the relationship, and score 9 meant strong relationship.

- Then, determined the technical importance and priority of structural design elements. There were two technical importance, they were technical importance absolute and technical importance relative.

Technical absolute importance was calculated using below formula that was adopted from Shrivastava \& Verma (2014).

$$
w_{j}=\sum_{i=1}^{n} d_{i} r_{i j} \quad ; i=1,2, \ldots n ; j=1,2, \ldots m
$$

Where:

$d_{i}=$ attribute importance level packaging structure of $\mathrm{i}$

$r_{i j}=$ score of the relationship between attributes of the packaging structure of $\mathrm{i}$ with design elements to the structure-j

Technical absolute relative was calculated using below formula that was adopted from Shrivastava \& Verma (2014).

$$
W_{j}=\frac{w_{j}}{\left(\sum_{j=1}^{m} w_{j}\right)} \quad, j=1,2, \ldots m
$$

2) Ratio, Consumer Assessment and Producer Target :

Likert scale was used for consumer assessment of the importance of secondary functions. Assessments ranged from 1 to 5 . The number 1 showed the value of "very unimportant", the number 2 showed the value of "not important", the number 3 showed "normal", the number 4 showed the value of "important", and the number 5 showed the value of "very important". Based on the results of data collection through a questionnaire of 30 consumers, each result of the importance level attribute packaging structure aggregated using mode method. The producer's target was the value of the importance given by the specialty coffee producers. On the right side of Figure 2 shows the values of importance.

3) Determining the correlation between Characteristics of Packaging Structure

This stage determined whether it had a strong positive relationship (++), positive (+), negative (-), and strong negative (-). If there was no relationship, then the assessment was left empty. 


\section{Packaging Structure Model Analysis Method}

At this stage the existing parameters were analysed by decision tree method with C4.5 algorithm technique. Decision Tree algorithm was very useful and well known for their classification (Lakshmi et al., 2013). Furthermore, Sapri et al. (2017) states decision trees were one of the most powerful directed data mining techniques because it could be used on such a wide range of problems and they generated models that explained how they work. The decision tree was a hierarchical structure to facilitate decision making. The $\mathrm{C} 4.5$ algorithm was introduced by J.R Quinlan (Quinlan, 1993). The C4.5 algorithm showed the time efficiency (Dai \& Ji et al., 2014). Stages in C4.5 algorithm method adopted from Sudrajat et al. (2017), were (1) Selecting elements as roots. To select elements as roots was based on the highest gain value from existing elements. The gain value was calculated by the formula:

Where :

$$
\operatorname{Gain}(S, A)=\operatorname{Entropy}(S)-\sum_{i=1}^{n} \frac{\left|S_{i}\right|}{|S|} * \operatorname{Entropy}\left(S_{i}\right)
$$

$S$ : case set

$A$ : Elements

n: number of attribute partition $A$

$\left|S_{i}\right|:$ Number of cases in the partition of $\mathrm{i}$

$|S|$ : number of cases in $S$;

While entropy is calculated by the formula:

Where :

$$
\operatorname{Entropy}(S)=\sum_{i=1}^{n}-P_{i} * \log _{2} P_{i}
$$

$S$ : case set.

$A$ : features

n: number of partitions $S$

$P_{i}$ : the proportion of $S_{i}$ against $S$

(2) Creating a branch for each value; (3) Dividing the case in the branch; (4) Repeating the process for each branch until all the cases on the branch have the same class. To support the analysis process, then Microsoft Excel was used. The output of this analysis was a decision tree model determining the structure of specialty coffee packaging. From the decision tree, rules were made to select specialty coffee packaging. The output of the packaging structure analysis model with the $\mathrm{C} 4.5$ algorithm technique was the rules for determining pouch packaging type.

\section{Results and Discussion:-}

1. Atribute analysis Influences The Packaging Structure

FAST diagram in this research was used to describe the logical connection function and attributes of the packaging structure. FAST diagram in Fig 1 was obtained based on the literature study and discussion with the consumers. An example of a logical relationship on a FAST diagram was done from left to right: "How the function of the packaging structure could be fulfilled?; How the packaging could have a practical appeal? With aesthetically pleasing and attractive, giving the impression of quality products, easy to hold and carry, and more. The order of functions was done from right to left: "Why was the aroma function of coffee easily recognizable? Because in order to have a practical appeal; Why should it have a practical appeal? Because in order to achieve the function of the packaging structure ".

Determination of packaging structures needed to pay attention to the practical attractiveness that was the effectiveness and efficiency of a packaging that was shown to the distributor and consumer (Wirya, 1999). According Julianti \& Nurminah (2007), the economic value should also be considered in designing the packaging. The practical appeal and economic value were the main function in designing this specialty coffee packaging. Both functions were interrelated and affect each other. The practical appeal showed how much the value of coffee packaging was due to the fulfilment of a function. The economic value indicated how much packing costs were required to fulfil all the desired/demanded functions.

The packaging structure attributes according to some literature were for aesthetically pleasing dan attractive (Krstic, 2014), gave an impression of premium quality, (Robertson, 2006; Julianti \& Nurminah, 2007; Julianti, 2014), easily held and carried (Soroka, 2009; Fatima et al., 2012; Sinaga et al., 2012; Julianti, 2014), easily opened and closed again Julianti \& Nurminah, 2007; Fatima et al., 2012, Krstic, 2014), Coffee aroma was easily recognizable (Soroka, 2009; Sinaga et al., 2012), recyclable (Krstic, 2014); reusable (Krstic, 2014); protectable for the coffee 
quality (Robertson, 2006; Soroka, 2009; Fatima et al., 2012; Sinaga et al., 2012; Julianti, 2014); good in size according to existing standards (Julianti \& Nurminah, 2007; Fatima et al., 2012); economical in price (Fatima et al., 2012; Sinaga et al., 2012; Wahyudi et al., 2013; Krstic, 2014).

Fig 1 shows that practical appeal had relevance to the economic value of specialty coffee packaging. FAST diagram shows the linkage function and attribute structure of specialty coffee packaging. Functions and attributes were validated (face validity) by experts in packaging design. Packaging structure attributes were used as the voice of customer on HOQ.

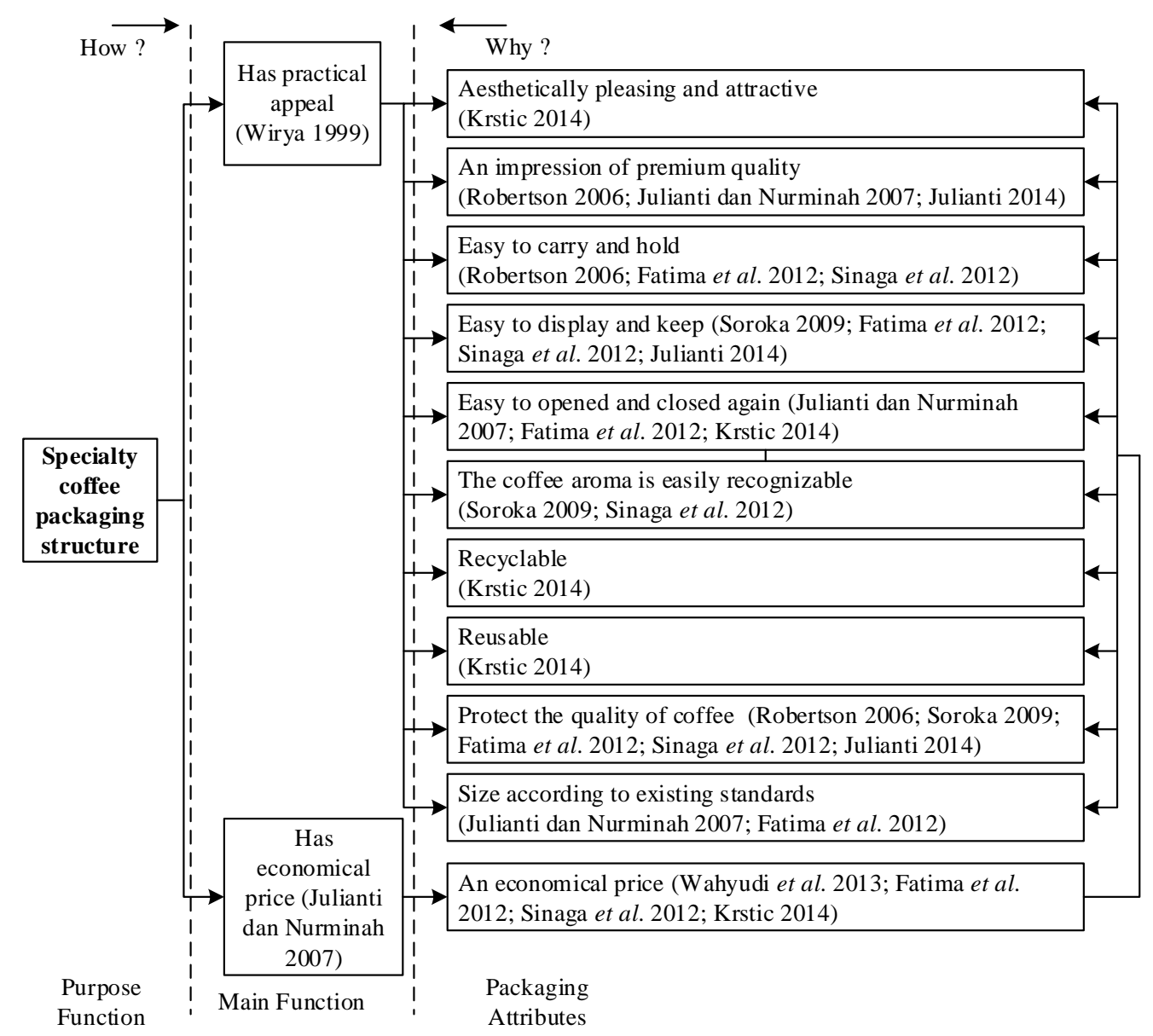

Fig. 1:- FAST Diagram of Specialty Coffee Packaging Structures

A. Weighted of Packaging Structure Attributes

This stage was conducted by weighting the interests of the packaging structure attributes with pairwise comparison method. The weighting results are shown in Table I. Consumer experience had a significant influence on its assessment on packaging and product quality (Holmes \& Paswan, 2012). Assessment by the three stakeholders were aggregated with the average geometry. Consistency Ratio value obtained was 0.04. This meant that comparative assessment was consistent, since Consistency Ratio was below 0.1.

Some attributes of packing structures with the greatest weight: 1$)$ were recognizable the coffee aroma easily (0.157), because consumers generally bought specialty coffee after exploring the aroma of coffee even though the coffee product was still in the packaging; 2 ) protected of the coffee quality (0.155), because to ensure the quality of aroma and sense of stay; 3 ) easily opened and closed again (0.146), because consumers want the practicality in using the product repeatedly; 4) gave an impression of premium quality $(0.115)$, because to convince consumers that the products contained in the packaging were highly qualified; and 5) economical price (0.090), because although premium product use of packaging must be effective and efficient. 
Table I:- Attribute Weight Of Specialty Coffee Packaging Structure

\begin{tabular}{|l|l|l|}
\hline No. & Packaging Structure Attribute & Weight \\
\hline 1 & Aesthetically pleasing and attractive & 0.050 \\
\hline 2 & Gives an impression of premium quality & 0.115 \\
\hline 3 & Easy to hold and carry & 0.081 \\
\hline 4 & Easy to display and keep & 0.030 \\
\hline 5 & Easily opened and closed again & 0.146 \\
\hline 6 & Coffee aroma is easily recognizable & 0.157 \\
\hline 7 & Recyclable & 0.062 \\
\hline 8 & Reusable & 0.044 \\
\hline 9 & Protect the coffee quality & 0.155 \\
\hline 10 & Size according to existing standards & 0.069 \\
\hline 11 & Economical price & 0.090 \\
\hline
\end{tabular}

\section{B. Structural Design Elements}

In order to effectively achieve customer satisfaction, the company not only knows what customers want but also knows the effort required on each elements (Afsar et al., 2011). The structural design elements were obtained from interviews of 7 business coffee shops (voice of company). The structural design elements were technical measures provided by business actors of the coffee shop (producer) on the packaging. The structural design elements consisted of elements of shape, material, and size (Rusko et al., 2011). Based on interviews with coffee business actors, structural design elements (shapes, materials, and sizes) were described to be more specific, as showed in Table II.

Shape, material, and packaging size were important elements of the packaging structure. This was supported by Clement et al. (2013), that the physical design features such as the shape and contrast (pouch) dominated the early phase of the search. Pouch had become the standard for specialty coffee packaging. Valve was a feature for consumers to enjoy the aroma of coffee even though the product is sealed in packaging. The use of zipper was to be easily opened and could be closed again, because this product was for repeatedly use (multi trip). Aluminium foil as the core material (inner), due to its permeability close to zero, it could prevent air and water vapour penetrate through the packaging. Thus, coffee was well protected if the packaging was made of aluminium foil. The using of preferred packaging size elements was to make the packaging attract (eye catching) while on the shelf display.

Table II:- Structural Design Elements

\begin{tabular}{|l|l|l|}
\hline No. & Structural Design Elements \\
\hline 1 & Shape & Packaging pouch \\
\hline 2 & \multirow{4}{*}{ Material } & Using valve \\
3 & & Using zipper \\
4 & & Surface material (outer) \\
5 & & Aluminium foil as inner \\
\cline { 3 - 3 } & & Surface material colour (outer) \\
\hline 7 & Size & Prefered packaging size \\
\hline
\end{tabular}

C. Development of Matrix Relationship Between Packaging Structure Attributes (What) with Structure Design Elements Matrix (How)

This matrix aimed to find out how strong the influence of the matrix How to matrix What (Akao, 2012). Assessment on this relationship matrix was analysed by calculating the absolute and relative importance of each structure design element. Then, priority of structural design elements were sorted. Priority of preferred structural design elements were obtained by sorting from highest to lowest values.

The order of priority on structural design elements, are 1) the use of zipper (4.94); 2) use of valve (4.57); 3) packaging pouch shape (4.13); 4) aluminium foil as core material (inner) (3.47); 5) the size of preferred packaging size $(2.32) ; 6)$ outer material $(1.75)$; and 7) colour of surface material (1.49). The relationship matrix between the packaging structure attribute and the structural design elements is showed in Figure 2.

The zipper element fulfiled some of the biggest attributes, which gave an impression of premium quality, easily opened and closed again, make coffee aroma easily recognizable, protect coffee quality, and had economical price. 
Valve usage satisfies some of the biggest attributes, such as an impression of premium quality, the easily recognizable aroma of coffee, protection of coffee quality, and the economical price. Meanwhile, packaging pouch forms fulfilled some of the biggest attributes, which gave an impression of premium quality, the easily recognizable aroma of coffee, and protection of coffee quality.

\section{House of Quality}

\begin{tabular}{|c|c|c|c|c|c|c|c|c|c|c|c|}
\hline $\begin{array}{l}\text { Correlation: } \\
++ \text { Strong Positive Correlation } \\
+\quad \text { Positive Correlation } \\
\text { + Negative Correlation } \\
\text { +. Strong Negative Correlation } \\
\text { None (Blank) }\end{array}$ & & Shape & . & + & $>$ & 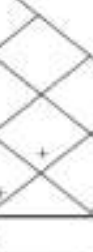 & $>$ & Size & & & \\
\hline Packaging Structure Atribute & $\frac{\frac{1}{2}}{\frac{20}{2}}$ & 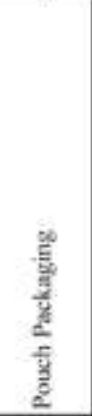 & $\frac{9}{\text { ले }}$ & $\frac{5}{5}$ & $\frac{\frac{5}{2}}{\frac{E}{2}}$ & 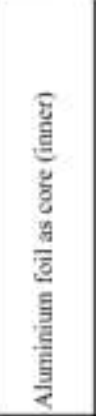 & 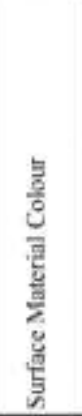 & $\frac{\frac{g}{2}}{\frac{E}{2}}$ & 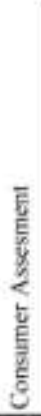 & 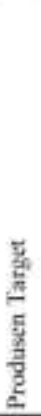 & $\frac{8}{2}$ \\
\hline Acsthetically pleasing and attractive & 0.050 & 9 & 9 & 9 & 3 & 9 & 9 & 9 & 4 & 4 & $4: 4$ \\
\hline Gives an impression of premium quality & 0.115 & 9 & 9 & 9 & 9 & 9 & 9 & 3 & 5 & 5 & $5: 5$ \\
\hline Easy to hold and carry & 0.081 & 9 & & & & & & 9 & 4 & 3 & $4: 3$ \\
\hline Easy to display and kecp & $0.0,30$ & 3 & & & & 9 & & 3 & 4 & 3 & $4: 3$ \\
\hline Easily opened and closed again & 0.146 & 3 & & 9 & & & & & 4 & 3 & $4: 3$ \\
\hline Coffee aroma is easily recognizable & 0.157 & & 9 & 3 & & & & & 5 & 3 & $5: 3$ \\
\hline Recyclable & 0.062 & & & & 3 & 3 & & & 3 & 3 & $3: 3$ \\
\hline Reusable & 0.044 & & & & & 1 & & & 3 & 3 & $3: 3$ \\
\hline Protect the coffee quality & 0.155 & 9 & 9 & 9 & & 9 & & & 5 & 4 & $5: 4$ \\
\hline Size according to existing standards & 0.069 & & & & & & & 9 & 5 & 4 & $5: 4$ \\
\hline Economical price & 0.090 & & 3 & 3 & & 1 & & 1 & 5 & 3 & $5: 3$ \\
\hline \multicolumn{2}{|l|}{ Technical Importance: Absolute } & 4.13 & 4.57 & 4.94 & 1.75 & 3.47 & 1.49 & 2.32 & & & \\
\hline \multicolumn{2}{|l|}{ Technical Importance: Relative } & $18.24 \%$ & $20.14 \%$ & $21.78 \%$ & $7,70 \%$ & $15.32 \%$ & $6.56 \%$ & $10.25 \%$ & & & \\
\hline \multicolumn{2}{|l|}{ Priority } & 3 & 2 & 1 & 6 & 4 & 7 & 5 & & & \\
\hline
\end{tabular}

Fig. 2:- House of Quality Matrix of Specialty Coffee Packaging Structures

D. Development of Matrix Correlation between Design Structure Elements (How)

The purpose of the correlation matrix between the packaging structure elements was to identify the relationship between the packaging structural elements that either support or against with each other. This matrix was located on the roof of HOQ in Figure 2. The results of the expert assessment showed no negative correlation (-) and no strong negative correlation (--) among structure design element. As examples of strong positive relationships on structural design elements were "packaged pouch " and "using zipper". Examples of positive correlation on the structural elements were "packaged pouch" and "outer material". While, examples of no correlation on the structural elements were "packaged pouch" and "preferred size packaging".

\section{Analysis of Specialty Coffee Packaging Structure With Pouch Type}

The structural design elements obtained from the QFD approach were used to generated decision tree model. The elements consisted of packaging pouch, using valve, using zipper, packaging outer material, aluminium foil, pouch surface colour, and packaging size. Packaging structure to be selected was the packaging pouch with the type of stand up pouch, side gusset pouch and flat bottom pouch. These types were the type of pouch that available in the market. 
The data obtained from coffee packaging suppliers were 116 of data showed the material elements of the packaging outer and the colour element of the pouch surface material were made into one element, which was the element of the surface material. While the element of aluminium foil material was removed due to all the available coffee packaging was already using aluminium foil material.

Entropy value was calculated on every parameter of each element. List of entropy values can be seen in table III. There are 3 times iteration based on the calculation. The iteration consisted of the $1^{\text {st }}$ iteration, the $2^{\text {nd }}$ iteration for value of type zipper $=$ standard zipper, the 2 nd iteration for value of type zipper $=$ no zipper, 3rd iteration with the standard child node zipper for surface material = kraft paper, 3rd iteration with the standard child node zipper for surface material $=$ matt silver, 3rd iteration with the standard child node zipper for surface material $=$ shiny black, 3rd iteration with the standard child node zipper for surface material = shiny white, 3rd iteration with the standard child node no zipper for surface material $=$ kraft paper, 3rd iteration with the standard child node no zipper for surface material $=$ matt silver, 3 rd iteration with the standard child node no zipper for surface material $=$ shiny black .

Table III:- Entropy VAlue of PACKaging Structure Parameters of SPECialty COFFEE

\begin{tabular}{|c|c|c|c|c|c|c|c|c|c|c|c|}
\hline \multirow{2}{*}{ Elements } & \multirow{2}{*}{ Parameters } & \multirow{2}{*}{$\begin{array}{l}\text { Iteration } \\
1\end{array}$} & \multicolumn{2}{|c|}{ Iteration 2} & \multicolumn{4}{|c|}{ Iteration $3(\mathrm{ZS})$} & \multicolumn{3}{|c|}{ Iteration 3 (TZ) } \\
\hline & & & ZS & TZ & PK & MS & SB & SW & PK & MS & SB \\
\hline \multirow{4}{*}{ Size } & $100 \mathrm{gr}$ & 0.00 & 0.00 & 0.00 & 0.00 & 0.00 & 0.00 & - & - & - & 0.00 \\
\hline & $150 \mathrm{gr}$ & 0.00 & 0.00 & - & - & - & - & 0.00 & 0.00 & - & - \\
\hline & $250 \mathrm{gr}$ & 1.50 & 0.89 & 0.99 & 1.00 & 1.00 & 1.00 & 1.00 & 1.00 & 1.00 & 1.00 \\
\hline & $500 \mathrm{gr}$ & 1.21 & 0.89 & 0.72 & 1.00 & 1.00 & 1.00 & 1.00 & 0.00 & 0.00 & 0.00 \\
\hline \multirow{3}{*}{ Zipper } & Standard Zipper & 0.00 & - & - & - & - & - & - & - & - & - \\
\hline & Pocket Zipper & 0.00 & - & - & - & - & - & - & - & - & - \\
\hline & No zipper & 0.00 & - & - & - & - & - & - & - & - & - \\
\hline \multirow{2}{*}{ Valve } & Yes & 1.41 & 0.78 & 1.00 & 0.97 & 0.97 & 0.97 & 0.97 & 0.92 & 0.92 & 0.97 \\
\hline & No & 1.41 & 0.78 & 1.00 & 0.97 & 0.97 & 0.97 & 0.97 & 0.92 & 0.92 & 0.97 \\
\hline \multirow{9}{*}{$\begin{array}{l}\text { Outer } \\
\text { Materials }\end{array}$} & Paper Kraft & 1.30 & 0.97 & 0.92 & - & - & - & - & - & - & - \\
\hline & Matt Silver & 1.30 & 0.97 & 0.92 & - & - & - & - & - & - & - \\
\hline & Matt Black & 0.00 & 0.00 & 0.00 & - & - & - & - & - & - & - \\
\hline & Matt White & 0.00 & 0.00 & 0.00 & - & - & - & - & - & - & - \\
\hline & Shiny Gold & 0.00 & 0.00 & - & - & - & - & - & - & - & - \\
\hline & Shiny Black & 1.50 & 0.97 & 0.97 & - & - & - & - & - & - & - \\
\hline & Shiny White & 0.00 & 0.97 & 0.00 & - & - & - & - & - & - & - \\
\hline & Shiny Red & 0.00 & 0.00 & - & - & - & - & - & - & - & - \\
\hline & Shiny Green & 0.00 & 0.00 & - & - & - & - & - & - & - & - \\
\hline
\end{tabular}

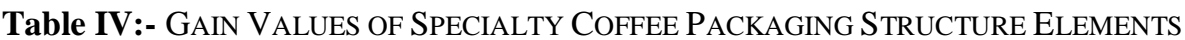

\begin{tabular}{|c|c|c|c|c|c|}
\hline \multirow{2}{*}{ Iteration } & \multirow{2}{*}{ Parameters } & \multicolumn{4}{|c|}{ Gain Value } \\
\hline & & Size & Zipper & Valve & Materials \\
\hline 1 & - & 0.28 & 1.41 & 0.00 & 0.65 \\
\hline \multirow{2}{*}{2} & Standard Zipper & 0.11 & - & 0.00 & 0.22 \\
\hline & No Zipper & 0.16 & - & 0.00 & 0.31 \\
\hline \multirow{4}{*}{$3(\mathrm{ZS})$} & Paper Kraft & 0.17 & - & 0.00 & - \\
\hline & Matt Silver & 0.17 & - & 0.00 & - \\
\hline & Shiny Black & 0.17 & - & 0.00 & - \\
\hline & Shiny White & 0.17 & - & 0.00 & - \\
\hline \multirow{2}{*}{$3(\mathrm{TZ})$} & Paper Kraft & 0.25 & - & 0.00 & - \\
\hline & Matt Silver & 0.25 & - & 0.00 & - \\
\hline
\end{tabular}

Description:

$\mathrm{ZS}=$ standard zipper; $\mathrm{TZ}=$ no zipper; $\mathrm{PK}=$ paper kraft; $\mathrm{MS}=$ matt silver SB $=$ shiny black; $\mathrm{SW}=$ shiny white

List of gain values can be seen in table IV. The gain value was calculated on each element's entropy value. The gain value was used to determine the root and node in the decision tree model. In table IV, iteration 1 shows that the highest gain value was a zipper element with a gain value of 1.41 . Then the zipper element became root with three branches (child node) which were the standard zipper, pocket zipper, and zipper. In the parameters of "standard 
zipper" and "zipper" became child node in iteration 2. Iteration 2 shows that the highest gain value was the element of surface material. The gain value of the surface material element was 0.22 with the standard child node zipper, and 0.31 with the child node no zipper.

Figure 3 shows decision tree model of determination of specialty coffee with type packaged pouch. This modelling produced 3 design elements of specialty coffee packaging structures, they were zipper, surface material, and size. While the valve element had no affect the structure of specialty coffee packaging, because the valve element could be installed on all types of packaging pouch.

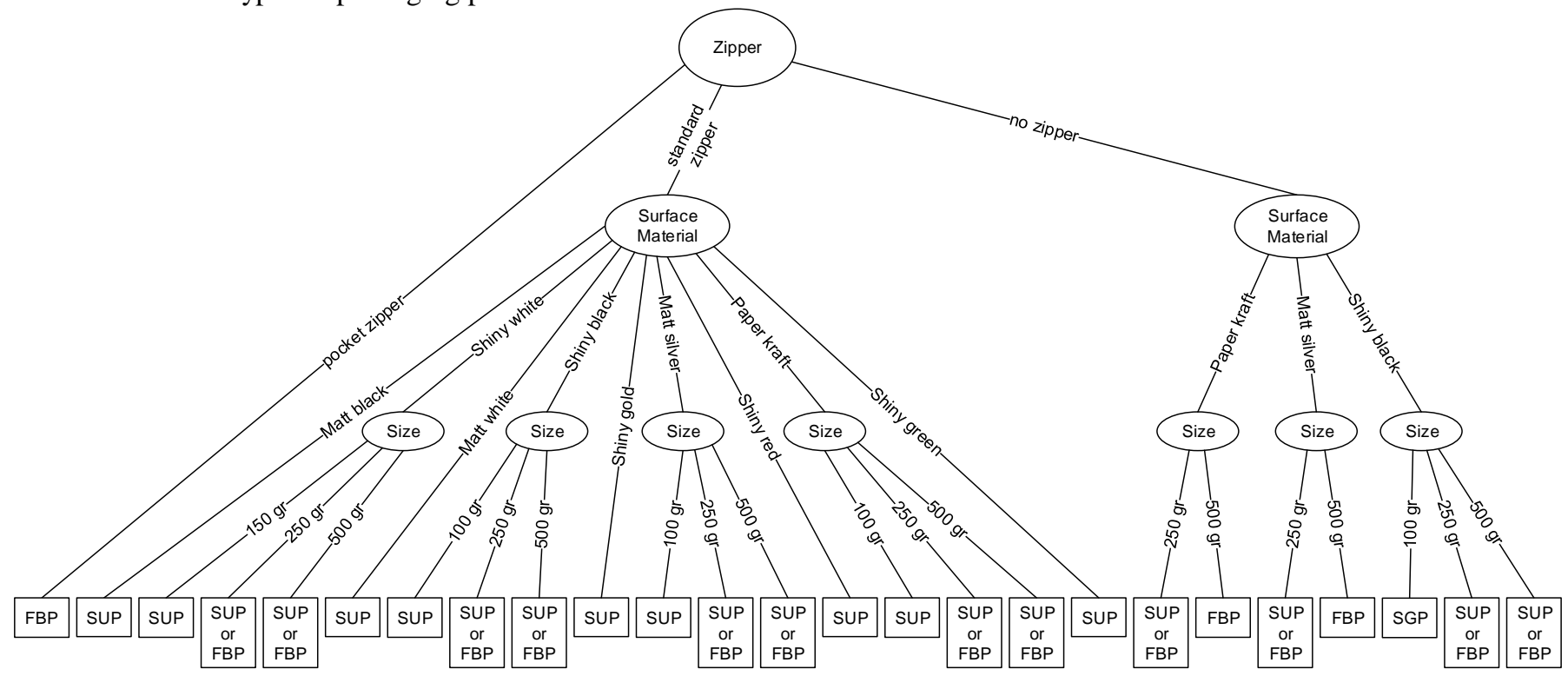

Description:

SUP $=$ stand up pouch

SGP $=$ side gusset pouch

FBP $=$ flat bottom pouch

Fig. 3:- Decision tree of determination specialty coffee packaging structure with pouch

A. Conversion of Decision Tree into Rules

Based on the decision tree model of specialty coffee packaging, the next step was converted into some of the rules. Table $\mathrm{V}$ shows 25 rules that were generated. The evaluation stage was done by testing each data set against the rules that had been generated. For example, if zipper $=$ standard zipper, surface material $=$ shiny black, size $=100 \mathrm{gr}$ then the packaging to be used was stand up pouch. The accuracy of model testing for the determination of pouch packaging type was $100 \%$.

\section{Managerial Implication}

The results of this study was expected to provide an understanding for business actors about the attributes and elements of the specialty coffee packaging structures that consumers wanted. In addition, this research facilitates the beginners and prospective business actors (coffee shop / roastery coffee) in decision-making pouch type packaging to be selected, taking into account the elements zipper, surface material, and size. 
Table V:- Rules Determination of Specialty Coffee PaCKaging Structure With Pouch TyPe

\begin{tabular}{|c|c|}
\hline No. & Rules \\
\hline 1 & IF zipper = pocket zipper, THEN pouch type = flat bottom pouch. \\
\hline 2 & IF zipper = standard zipper, surface material = matt black, THEN pouch type $=$ stand up pouch. \\
\hline 3 & IF zipper = standard zipper, surface material $=$ matt white, THEN pouch type $=$ stand up pouch. \\
\hline 4 & IF zipper = standard zipper, surface material $=$ shiny gold, THEN pouch type $=$ stand up pouch. \\
\hline 5 & IF zipper $=$ standard zipper, surface material $=$ shiny red, THEN pouch type $=$ stand up pouch. \\
\hline 6 & IF zipper = standard zipper, surface material = shiny green, THEN pouch type = stand up pouch. \\
\hline 7 & $\begin{array}{l}\text { IF zipper }=\text { standard zipper, surface material }=\text { shiny white, size }=150 \mathrm{gr} \text {, THEN pouch type }=\text { stand up } \\
\text { pouch. }\end{array}$ \\
\hline 8 & $\begin{array}{l}\text { IF zipper }=\text { standard zipper, surface material }=\text { shiny white, size }=250 \mathrm{gr} \text {, THEN pouch type }=\text { stand up } \\
\text { pouch or flat bottom pouch. }\end{array}$ \\
\hline 9 & $\begin{array}{l}\text { IF zipper }=\text { standard zipper, surface material }=\text { shiny white, size }=500 \mathrm{gr} \text {, THEN pouch type }=\text { stand up } \\
\text { pouch or flat bottom pouch. }\end{array}$ \\
\hline 10 & $\begin{array}{l}\text { IF zipper }=\text { standard zipper, surface material }=\text { shiny black, size }=100 \mathrm{gr}, \text { THEN pouch type }=\text { stand up } \\
\text { pouch. }\end{array}$ \\
\hline 11 & $\begin{array}{l}\text { IF zipper }=\text { standard zipper, surface material }=\text { shiny black, size }=250 \mathrm{gr} \text {, THEN pouch type }=\text { stand up } \\
\text { pouch or flat bottom pouch. }\end{array}$ \\
\hline 12 & $\begin{array}{l}\text { IF zipper }=\text { standard zipper, surface material }=\text { shiny black, size }=500 \mathrm{gr} \text {, THEN pouch type }=\text { stand up } \\
\text { pouch or flat bottom pouch. }\end{array}$ \\
\hline 13 & IF zipper $=$ standard zipper, surface material $=$ matt silver, size $=100 \mathrm{gr}$, THEN pouch type $=$ stand up pouch \\
\hline 14 & $\begin{array}{l}\text { IF zipper }=\text { standard zipper, surface material }=\text { matt silver, size }=250 \mathrm{gr}, \text { THEN pouch type }=\text { stand up pouch } \\
\text { or flat bottom pouch. }\end{array}$ \\
\hline 15 & $\begin{array}{l}\text { IF zipper }=\text { standard zipper, surface material }=\text { matt silver, size }=500 \mathrm{gr}, \text { THEN pouch type }=\text { stand up pouch } \\
\text { or flat bottom pouch. }\end{array}$ \\
\hline 16 & $\begin{array}{l}\text { IF zipper }=\text { standard zipper, surface material }=\text { paper kraft, size }=100 \mathrm{gr} \text {, THEN pouch type }=\text { stand up } \\
\text { pouch. }\end{array}$ \\
\hline 17 & $\begin{array}{l}\text { IF zipper }=\text { standard zipper, surface material }=\text { paper kraft, size }=250 \mathrm{gr}, \text { THEN pouch type }=\text { stand up pouch } \\
\text { or flat bottom pouch. }\end{array}$ \\
\hline 18 & $\begin{array}{l}\text { IF zipper }=\text { standard zipper, surface material }=\text { paper kraft, size }=500 \mathrm{gr}, \text { THEN pouch type }=\text { stand up pouch } \\
\text { or flat bottom pouch. }\end{array}$ \\
\hline 19 & $\begin{array}{l}\text { IF zipper }=\text { no zipper, surface material }=\text { paper kraft, size }=250 \mathrm{gr} \text {, THEN pouch type }=\text { side gusset or flat } \\
\text { bottom pouch. }\end{array}$ \\
\hline 20 & IF zipper = no zipper, surface material $=$ paper kraft, size $=500 \mathrm{gr}$, THEN pouch type $=$ flat bottom pouch. \\
\hline 21 & $\begin{array}{l}\text { IF zipper }=\text { no zipper, surface material }=\text { matt silver, size }=250 \mathrm{gr}, \mathrm{THEN} \text { pouch type }=\text { side gusset pouch or } \\
\text { flat bottom pouch. }\end{array}$ \\
\hline 22 & IF zipper = no zipper, surface material $=$ matt silver, size $=500 \mathrm{gr}$, THEN pouch type $=$ flat bottom pouch. \\
\hline 23 & IF zipper = no zipper, surface material $=$ shiny black, size $=100$ gr, THEN pouch type $=$ side gusset pouch. \\
\hline 24 & $\begin{array}{l}\text { IF zipper }=\text { no zipper, surface material }=\text { shiny black, size }=250 \mathrm{gr}, \text { THEN pouch type }=\text { side gusset pouch or } \\
\text { flat bottom pouch. }\end{array}$ \\
\hline 25 & $\begin{array}{l}\text { IF zipper }=\text { no zipper, surface material }=\text { shiny black, size }=500 \mathrm{gr}, \text { THEN pouch type }=\text { side gusset pouch or } \\
\text { flat bottom pouch. }\end{array}$ \\
\hline
\end{tabular}

\section{Conclusions and Recommendation:-}

Consumer preferences were analyzed with: 1) FAST and pairwise comparison method, we found 5 attributes of packaging structure with the biggest weight, they were coffee aroma was easily recognizable $(0.157)$, protected coffee quality (0.155), easy to opened and closed again (0.146), gave the impression of quality product $(0.115)$, and an economical price (0.090); 2) QFD approach (HOQ analysis) generated the priority of structural design elements that were sequentially, using zipper (4.94), using valve (4.57), packaging pouch (4.13), aluminium foil as inner (3.47), most preferred size (2.32), outer surface material (1.75), and colour of surface material (1.49).

This research has succeeded in formulating decision making model (decision tree) to determine pouch type packaging based on packaging structure elements (zipper, surface material, and size). Level of accuracy on model testing for the determination of packaging with pouch type of $100 \%$. Valve element has no effect in determination of 
pouch type packaging, but every pouch type chosen based on consumer preference analysis result must be equipped with valve.

This study has analized the specialty coffee packaging from the side of the structure attributes and packaging structure elements. For further research is expected to analyze the specialty coffee packaging from the graphic attribute (label) and packaging graphic elements. Finally, this research have successfully analysed specialty coffee packaging from the attribute side and packaging structure elements. For the further research, it is expected to analyse specialty coffee packaging from attribute side and packaging graphic element.

\section{References:-}

1. Abidin SZ, Effendi RAARA, Ibrahim R, Idris MZ. 2014. A semantic approach in perception for packaging in the SME's food industries in Malaysia: a case study of Malaysia food productbranding in United Kingdom. Procedia- Social and Behavioral Sciences, 115: 115-130.

2. Afsar M, Feizi K, Afsar A. 2011. An integrated method of quality function deployment, Kano's model and hierarchical decision making for improving e-service of brokerage in Iran. African Journal of Business Management, vol. 5 (11), pp. 4510-4518.

3. Akao Y. 2012. The Method for Motivation by Quality Function Deployment (QFD). J Nang Yan Bus, vol. 1 (1), pp. 1-9.

4. Clement J, Kristensen T, Grønhaug K. 2013. Understanding consumers' in-store visual perception: The influence of package design features on visual attention. Journal of Retailing and Consumer Services, vol. 20(2), pp. 234-239. https://doi.org/10.1016/j.jretconser. 2013.01.003.

5. Dai W, Ji W. 2014. A MapReduce Implementation of C4.5 Decision Tree Algorithm. International Journal of Database Theory and Application, vol. 7(1), pp. 49-60. http://dx.doi.org/10.14257/ijdta. 2014.7.1.05.

6. Fatima R, Rahmaniyah DA, Priadythama I. 2012. Perancangan kemasan obat tradisional menggunakan metode Quality Function Deployment. Prosiding Seminar Nasional Aplikasi Sains \& Teknologi Periode III. Pp. 129135 ,

7. Gadung A, Zakaria WA, Murniati K. 2015. Analisis Kepuasan dan Loyalitas Konsumen Kopi Bubuk Sinar Baru Cap Bola Dunia (SB-CBD) di Kota Bandar Lampung. JIIA, vol. 3(4), pp. 370-376.

8. Harith ZT, Ting CH, Zakaria NNA. 2014. Coffee packaging: Consumer perception on appearance, branding and pricing. International Food Research Journal, vol. 21(3), pp. 849-853.

9. G. R. Holmes, A. Paswan. 2012. Consumer reaction to new package design. Journal of Product \& Brand Management, vol. 21 (2), pp. 109-116, https://doi.org/10.1108/ 1061042121121 5553.

10. Julianti E, Nurminah M. 2007. Buku Ajar: Teknologi Pengemasan. Fakultas Pertanian: Universitas Sumatra Utara.

11. Julianti S. 2014. The Art of Packaging : Mengenal Metode, Teknik, dan Strategi Pengemasan Produk untuk Branding dengan Hasil Maksimal. Jakarta: PT Gramedia Pustaka Utama.

12. Krstic J. 2014. Using possibility of QFD method for development of the "Ready-To-Go" package. Jurnal ACTA GRAPHICA, vol. 25, pp. 37-46.

13. Lakshmi TM, Martin A, Begum RM, Venkatesan VP. 2013. An Analysis on Performance of Decision Tree Algorithms using Student's Qualitative Data. I.J.Modern Education and Computer Science,vol. 5, pp. 18-27. DOI: $10.5815 /$ ijmecs.2013.05.03.

14. Mohebbi B. 2014. The art of packaging: An investigation into the role of color in packaging, marketing, and branding. International Journal of Organizational Leadership. vol. 3, pp. 92-102.

15. Moutaftsi P, Kyratsis P. 2016. Visual Brand Identity of Food Products : a Customer's Perspective. Journal of Applied Packaging Research, vol. 8 (3), pp. 1-14. DOI: 10.14448/japr.08.0015.

16. Piccino S, Boulanger R, Descroix F, Sing ASC. 2014. Aromatic composition and potent odorants of the "specialty coffee" brew "Bourbon Pointu" correlated to its three trade classifications. Food Research International, 61, pp. 264-271.

17. Quinlan JR. 1993. C4.5: Programs for Machine Learning, 1st Edition. Morgan Kaufmann.

18. Robertson GL. 2006. Food Packaging: Principles and Practice, Second edition. CRC Press.

19. Rusko E, Heinio S, Korhonen V, Heilmann J, Karjalainen TM, Lahtinen P, Pitkanen M. 2011. Messenger Package - Integrating Technology, Design and Marketing for Future Package Communication. Final Report, VTT Tiedotteita - Research Notes 2586. 90 p.

20. Saaty TL, Vargas LG. 2012. Models, Methods, Concepts \& Applications of the Analytic Hierachy Process, 2nd ed. New York, US: Springer. 
21. Sapri FE, Nordin NS, Hasan SM, Yaacob WFW, Nasir SAM. 2017. Decision Tree Model for Non-Fatal Road Accident Injury. International Journal on Advanced Science Engineering Information Technology, vol. 7 (1), pp. 63-70.

22. Satyajaya W, Rangga A, Nurainy F, Al Rasyid H. 2014. Proses Pengambilan Keputusan Konsumen dan Atribut Produk Kopi Instan Dalam Sachet. Jurnal Teknologi Industri dan Hasil Pertanian, vol. 19 (3), pp. 297306.

23. Shrivastava P, Verma DS. 2014. Application of Quality Function Deployment To Improve Customer Satisfaction In Hotel Industry (A case study in a 5-star Hotel). International Journal of Scientific \& Engineering Research, vol. 5, Issue 6.

24. Sinaga FB, Evanila S, Dewi KH. 2012. Pemilihan kemasan sekunder cabai blok dengan metode AHP, tingkat kesukaan konsumen dan nilai tambah. Jurnal Agroindustri, vol. 2(2), pp. 62-69.

25. Soroka W. 2009. Fundamentals of Packaging Technology. Institut of Packaging Professionals: USA.

26. Sudrajat R, Irianingsih I, Krisnawan D. 2017. Analysis of data mining classification by comparison of C4.5 and ID algorithms. IOP Conf. Ser.: Mater. Sci. Eng., 166, 012031, doi:10.1088/1757-899X/166/ 1/012031.

27. Suryaningrat IB. 2016. Implementation of QFD in Food Supply Chain Management: A Case of Processed Cassava Product in Indonesia. International Journal on Advanced Science Engineering Information Technology, vol. 6 (3), pp. 302-305.

28. Udayana IGB. 2015. Model Development Industrial Cluster Coffee Arabica in The District Bangli, Province of Bali. International Journal on Advanced Science Engineering Information Technology, vol. 5 (4), pp. 294-297.

29. Wahyudi R, Supartono W, Khuriyati N. 2013. Analisis Mutu Produk dan Kemasan Lempuk Durian (Durio Zibethinus SP). Jurnal Industri, vol. 2(1): 1-8.

30. Wirya I. 1999. Kemasan Yang Menjual. Jakarta: PT Gramedia Pustaka Utama,

31. Zekiri J. 2015. The Role And Impact Of The Packaging Effect On Consumer Buying Behaviour. Ecoforum Journal, vol. 4(1), pp. 232-240. 